\title{
Community-led practices for triggering long term processes and sustainable resilience strategies. The case of the eastern Irpinia, inner periphery of southern Italy
}

\author{
Katia Fabbricatti $^{1 *}$, Lucie Boissenin ${ }^{2}$, Michele Citoni ${ }^{3}$ and Vincenzo Tenore ${ }^{4}$ \\ ${ }^{1}$ Department of Architecture DiArc, University of Naples "Federico II"/ via Tarsia 31, 80135 \\ Naples (Italy) \\ ${ }^{2}$ LabEx Architecture, Environment and Building Cultures, Grenoble School of Architecture, Univ. \\ Grenoble Alpes/ 60 avenue de Constantine, 38036 Grenoble \\ ${ }^{3}$ ACT Antropologia Cultura Territorio/ Via Festo Avieno 230, 00136 Rome (Italy) \\ ${ }^{4}+$ tstudio / Corso Vittorio Emanuele 110, 83041 Aquilonia (AV), Italy \\ E-Mails: katia.fabbricatti@unina.it; boissenin.l@grenoble.archi.fr; mi.cito@libero.it; \\ architetto.tenore@gmail.com
}

* Author to whom correspondence should be addressed; Tel.: +39-339-8814015

\begin{abstract}
The value of the cultural heritage and its transmission for "making cities and human settlements inclusive, safe, resilient and sustainable" and for Disaster Risk Reduction is an integral part of the Agenda 2030 of the United Nations. The Council of Europe's Framework Convention on the Value of Cultural Heritage for Society, originating from war and anthropogenic violations of cultural heritage, marks a milestone in the transition process towards a social approach to cultural heritage. With the notion of "heritage community", attention shifts from the cultural heritage in itself, towards people, their relationship with the surrounding environment and their active participation in the process of recognizing the values held in it and their transmission to future generations.

In the European inner peripheries, cultural heritage has peculiarities that distinguish it from core areas. It is affected by extreme global and local risks. The paper describes the case of the Irpinia, an inner periphery of the southern Italy. Here, in the course of few years many community-led practices have been developed, based on the reinterpretation and renewal of the local material culture. These actions have reinforced the networking of local actors and their "awareness of place". In this scenario, a group of researchers, designers, scholars proposes to carry out Resilience Laboratories as places of learning, participation and decision. They must start the process of building a resilient and sustainable landscape and, in the medium to long term, act as permanent support to the traditional regulatory tools for risk management.
\end{abstract}


Keywords: cultural heritage/ landscape; heritage community; community resilience; inner peripheries; community-led practices

\section{Introduction}

The concept of resilience, a term often abused in the debate on the models of regeneration, development, management and maintenance of urban social systems, is in effect a global challenge, launched by the World Agenda, to which the Member States are trying to respond. The term evokes the need to change the approach to continue to guarantee sustainable policies to address the environmental, social and economic changes that are affecting our territories (Holling 2001). One of the most shared definition of the term describes resilience as «the capacity of a system to absorb disturbance and reorganize so as to retain essentially the same function, structure, and feedbacks to have the same identity» or more simply «the ability to cope with shocks and keep functioning in much the same kind of way» (Walker and Salt 2012). Therefore, a resilient system is characterized by a capacity for persistence (strong identity), at the same time by a capacity of learning (reorganize) to adapt, or to transform, part or all of the system, into a different kind of system (in the case of an irreversibly undesirable state) (O’Connell et al. 2015).

In this sense, resilience evokes the necessity to combine the dynamic and adaptive dimension of the urban systems with the necessity to strengthen and innovate their identity values.

The value of cultural heritage/landscape (European Spatial Development Perspective ESDP1999, European Landscape Convention 2000, Codice dei Beni Culturali e del Paesaggio 2004, Council of Europe's Framework Convention on the Value of Cultural Heritage for Society 2005, UNESCO Recommendations 2011) for the construction of sustainable and resilient human settlements is recognised in international documents and agendas. At the same time, these documents highlight the importance of the sharing and participation of civil society in achieving the objectives of the world agenda (UN 2015, target 11.3; UNISDR 2015, Sendai Framework, paras 19d).

However, the processes by which the community can contribute through cultural heritage to resilient and sustainable human settlements are still a matter of study, especially in so-called "slow" or "fragile" contexts (Beel et al. 2017).

In the inner peripheries, the link between the population and the heritage has peculiar characteristics compared to the core areas. The low number of inhabitants, combined with deeply rooted cultural traditions - often still evident in daily practice as well as in the landscape - generate a community cohesive around collective values and history, linked to its places of life (Fusco Girard 2013).

The contribution starts from these themes to analyze, through the approach of resilience thinking, "good practices of resilience" carried out in Alta Irpinia, a territory in southern Italy, where the cultural and social capital act as a driver and enabler. Such practices, represented by cultural 
creative productions (Cerreta et al. 2018) - festivals, workshops, adaptive reuse projects, etc. - are carried out by the community in its different forms - organized into groups, associations, committees, etc. - in some cases with the support of institutions. Through actions of promotion of tangible and intangible cultural heritage, they stimulate processes of building heritage communities (Council of Europe 2005, art. 2b) and at the same time contribute to developing the adaptive capacity of the population.

The objective of the analysis is to understand the elements of the practices that contribute to the resilience of the social-urban system, with particular attention to community resilience. Furthermore, based on the results of the analysis, the paper proposes to carry out Resilience Laboratories as places of learning, participation and decision making. Through monitoring and cocreation actions, they should start the process of building a resilient and sustainable landscape and, in the medium to long term, act as permanent support to the traditional regulatory tools for managing uncertainty and change (Pinto et al. 2018).

\section{State of the Art}

The reactivation of the system of relations between the place - understood as a deposit of values produced over time by populations and recognized as such in their diversity (UNESCO 2011) - and the community - understood as an open set of people linked to a local context by different factors (Magnaghi et al. 2017) - is a key action to pursue the objectives of sustainability and resilience of the world agendas (UN 2015; UNISDR 2015).

Agenda 2030 for Sustainable Development (UN 2015) is a privileged reference point for a comparison between the radical transformations affecting the settlement fabric of cities and the challenges they are called upon to face today, in the scenario of global competition. Within the 17 SDGs that make up the Agenda, the conservation and promotion of cultural heritage are transversal drivers: «Culture is who we are, and what shapes our identity. Placing culture at the heart of development policies is the only way to ensure a human-centred, inclusive and equitable development» (Hosagrahar 2015). In particular, Objective 11"Make cities and human settlements inclusive, safe, resilient and sustainable" highlights the need to strengthen efforts to protect and safeguard the world's cultural and natural heritage (11.4), to strengthen inclusive and sustainable urbanisation and to plan and manage participatory, integrated and sustainable human settlement in all countries (11.4).

In the same year (2015) and for the first time, cultural heritage was recognised as playing a role in addressing global risks within the new international policy for disaster risk reduction, adopted during the Third United Nations World Conference Disaster Risk Reduction (WCDRR), at Sendai, Japan (Sendai Framework 2015-2030). During the conference, in fact, the effectiveness of the cultural heritage is highlighted in understanding disaster risks and strengthening governance, investing in resilience and preparing for response, recovery and reconstruction. The heritage, both tangible and intangible, incorporates useful elements to overcome potential risks, being the result of long periods of adaptation between man and his environment; cultural heritage can be a powerful 
catalyst for interacting with local populations, bringing them together and reinforcing the sense of belonging in the preventive and recovery phases; moreover, the protection of the cultural heritage can sustain a rapid recovery through the economy generated in the sectors linked to tourism activities. In this perspective, new stakeholders belonging to the cultural sector and new roles also for local populations are identified for the Disaster Risk Reduction. «Indigenous peoples, through their experience and traditional knowledge, provide an important contribution to the development and implementation of plans and mechanisms, including for early warning. [...] Academia, scientific and research entities and networks [provide] to: focus on the disaster risk factors and scenarios, including emerging disaster risks, in the medium and long term; increase research for regional, national and local application; support action by local communities and authorities; and support the interface between policy and science for decision-making» (point 36).

In the Sendai Framework it emerges, therefore, that the community can play an active role in the protection of its cultural heritage and in the enhancement of the resilience of the socio-urban system (phase of prevention, response, recovery and reconstruction), precisely because it is the repository of the local culture. In this sense, we can speak of a "heritage community", in the meaning identified by the 2005 Faro Convention, as «people who value specific aspects of cultural heritage which they wish, within the framework of public action, to sustain and transmit to future generations» (art. 2b). At the same time, cultural heritage acquires a key role in the global agendas to increase the resilience of the community. The latter can be defined as «people's ability to learn and change (which, in turn, is partially determined by the institutional context for knowledge sharing, learning, and management, and partially by the social capital among people)» (Gunderson and Folke 2005). It contributes, together with the system's capacity for renewal in a dynamic environment, to the general resilience of the social-ecological system.

From these reflections, it is possible to draw as an assumption that a heritage community is the basis of a resilience community.

\section{1 "Heritage communities" in European and Italian inner peripheries}

Inner peripheries represent in our opinion a kind of "laboratory" to study the issues of the heritage communities and the community resilience. They are the result of the secular interaction of man with his environment of life: the geographical characteristics, the nature of the territory are the recurring parameters of settlement (Biancamano et al. 2013) and of the land use. Moreover, they are specific contexts where it is possible to retrace «a vitality, a particular humanity, due to still existing forms of micro-communities and networks of personal face to face relationships» (Fusco Girard 2013). Indeed, their non-accessibility preserve them from mass tourism and massive economic development which would have upset the ecosystems (Settis 2005).

The term "inner peripheries" is defined by the European "ESPON 2020" research program "national territories facing challenges of access to basic services of general interest" (ESPON 2017). This definition goes further than the traditional distinction between urban and rural areas, city and countryside, referring to the "disconnection from external territories and networks" (ibid.). 
The issue of "inner peripherality" is shared by all the countries of the European continent (Fig.1).

Figure1. European inner peripheries.

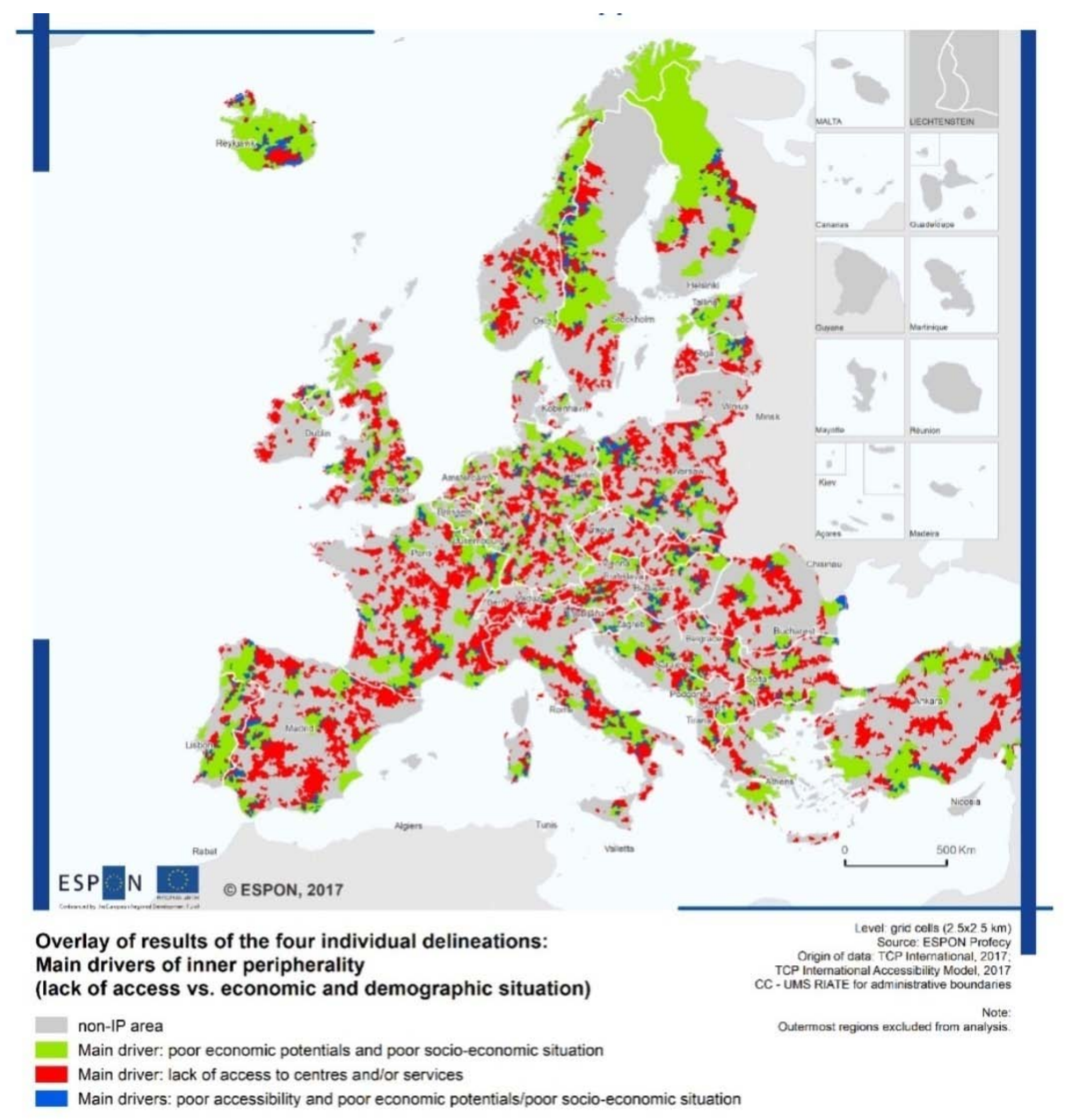

AAVV. 2017. Op. Cit., p .17.

Despite a previous commitment by Member States to reduce territorial inequalities (ESDP 1999), the issue is more and more current and these areas still have to face important and extensive risks: the ageing of the population, the out-migration of the young graduates, the erosion of cultural capital and identity of places, the degradation of the landscapes with the uncontrolled exploitation of the soil, the abandonment of agricultural land, etc.

In order to try to face the risks they are subjected to, in recent times inner peripheries are becoming incubators of community-led practices drawing on cultural heritage. We observe that cultural heritage is often mobilized in these processes, and we identify two recurring approaches. The first one is a "resistance" attitude. The second one is a more productive approach: after a moment of rediscovering the "territorial capital" (Camagni 2017), the community imagine new ways to highlight some of the identified assets to create new economic activities. In some territories, the communities begin with a resistance attitude to move afterwards into a productive 
approach (Magnaghi 2012). In both approaches, the ability of the community to meet, with the aim of responding to some risks and evaluating alternatives, represents a strong asset in a resilience perspective.

In the Italian context, we can observe that the inner peripheries are subject to the same type of risks, although it is worth highlighting in particular the problems of out-migration of young people, the ageing of the population and the difficulties in maintaining the natural and cultural heritage.

From previous researches (Pinto et al. 2018, Battaglini and Corrado 2014, etc.) some encouraging signs of top-down and bottom-up practices emerge in Italy that combine conservation and enhancement of cultural heritage with the responses to the challenges of marginalized areas.

The urgency of the topic has pushed national politics to mobilize national and regional resources for the so-called National Strategy for Inner Areas. Preparatory studies have revealed that a significant part of the national territory is concerned (60\% of the surface, $52 \%$ of the municipalities, $22 \%$ of the population) (Fig. 2). The National Strategy recognizes that the country's development cannot improve without addressing the issue of marginalization of a large part of the territory and without involving local communities. Thus, it provides for the implementation of participatory processes, in each of the 72 selected areas, involving its major stakeholders also to spread a "culture of inner areas”.

Figure 2. Italian inner areas.

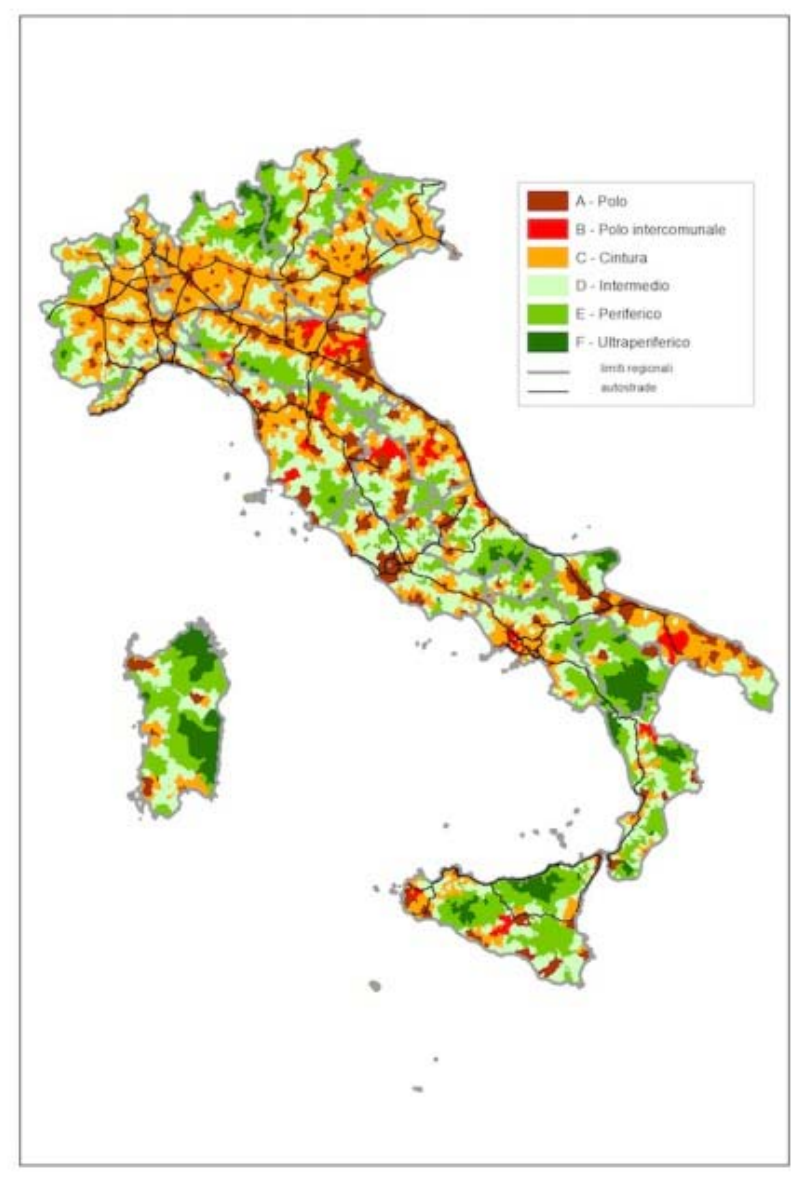

AA.VV. 2014. Op. Cit., p. 27. 
At the same time, several research groups have been set up to constitute observatories of good bottom-up practices flourishing in Italy, such as the "Territorialist School" or the "Fragile Areas network". They cover a wide range of experiences, which express the diversity of solutions used according to the particularities of the territories: agreements between the community and institutions or between different categories of actors (management of common goods); forms of specific and/or conflicting interventions (occupations, resistance actions); socio-economic experiments (productive dimension with social component); cultural creative productions (festivals, workshops, adaptive reuse projects, etc.). In addition, the return of young people who had emigrated to study, or the decision to stay in their own territories, with the aim of starting up businesses, is a trend that deserves to be observed.

In conclusion, we can consider inner peripheries an environment conducive to enhance "heritage communities" and "community resilience". In these territories, the actions pursue the dual objective of preserving cultural heritage and strengthening the cohesion of the local community on recognized values of general interest, affecting users' ability to adapt, on the level of transformability of the system and on the reactivity of the bio-ecological components (Agosti et al. 2018). Unfortunately, these practices at this time are not sufficient to reverse the disconnection and depopulation processes, in part because they are isolated cases and not integrated into a territorial policy (Terranova 2017).

\section{Methodology}

The research examines three good practices based on the enhancement of cultural heritage. They are temporary cultural creative experiences, carried out by the local community, in some cases with financial support guaranteed by the institutions.

The selected good practices belong to the same territorial context, and therefore generally face the same risks and pressures. However, they present significant differences, both in terms of morphological, settlement, socio-demographic and economic characteristics, and in terms of objectives, strategies, actors involved and governance.

The choice of comparing three good practices belonging to the same territorial context can help in defining the elements of replicability, providing general indications for the construction of community resilience.

The comparison was made using a comparative sheet that analyses 6 categories of data: general information, actors, implementation, results, cultural heritage, resilience.

The "general information", in addition to reporting the current state of the three practices and the their specific objectives, allow us to frame the main characteristics of the context in which they take place, highlighting the local peculiarities.

The section on "actors" identifies the target communities and the final beneficiaries, organizing the subjects involved by roles and competences (activators, organizers, and facilitators, economic partners). 
In the "implementation" section, data are inserted that put the drivers of the practices in a system, indicating the strategies adopted, the actions carried out and the subjects that participate in the governance.

The "results" section presents the short and medium term effects of the practices, highlighting in particular the fallout on the awareness of the values of the territory by the local populations, on the development of cultural and economic processes, as well as on the activation of networks at different scales.

The following categories of "resilience" and "cultural heritage" help to assess the issues developed in this research. In particular, the category of "resilience" indicates, in the first place, the risks and pressures on which the resilience of the practice and the vulnerabilities of the territory related to the risks are assessed. Subsequently, the effects of the practice on the resilience of the socio-urban system are made explicit through the use of Resilient Systems Qualities, a performance support developed by Arup in the City Resilience Framework (Arup 2014). Finally, the "cultural heritage" section, which refers to heritage in the dual category of material and immaterial, examines, on the one hand, its role in the implementation of practices, and on the other hand, the effects that the practices themselves have on its conservation/maintenance and enhancement.

The sources of the data are different, so are the methods of observation, direct and indirect. The three practices, in fact, despite the involvement of experts, show, among their elements of fragility, a non generalized capacity to produce self-analysis data. Official documents (calls for tenders, contracts, calls, posters, etc.), media sources (main newspapers, google trends, etc.) and semistructured interviews with the main actors were used.

\section{Case studies}

The three practices studied in this article are located in a single territorial context: Eastern Irpinia. It is a part of the Avellino Province, in the Southern Italy. It has been selected as "pilot area” by the Cohesion Agency, among four inner areas of Campania Region, to test the National Strategy for Inner Areas (AA.VV. 2014).

Several issues are weakening this area. First of all, the depopulation process: between 2001 and 2011, «the population decreased by 5.8\%, exceeding both the regional (1.4\%) and the national (2.3\%) average for non-core areas» (Oppido et al. 2018). The main cause is the out-migration: peopleleft the territory to find working opportunities somewhere else. The second weakness, which is connected to the first one, is the ageing of the population. The 'over 65' represents $30 \%$ of the population of the area (ISTAT data). In this context, the difficulty of accessing health care takes on an even more alarming dimension. The third major weakness is the erosion of cultural capital and territorial identity, which are mainly challenged by external pressures on local resources: the landscape is frequently threatened by wind turbine, oil drilling and landfill projects.

However, over the past twenty years, there have been community-led processes to rediscover the specific local assets, starting from guided tours of rediscovering the territory and conferences on the theme of landscape to real processes of regeneration (opening of hotels in some restored villages, 
revival of ancient cultivations, certification of food and wine production, reopening of a railway line, etc..). In addition, the local press reports on cases of returns or permanency of young people in the territory. We can then hypothesize that a "heritage community" is emerging in Irpinia and contributes to the affirmation of the idea that a new social and economic development is possible, which would be based this time on the valorization of local resources (unlike the post-earthquake strategies of the 1980s which parachuted industrial nuclei into the valleys).

Among the cultural-led practices that have developed in recent years in Irpinia, we have selected three particular cases. The first one is the SponzFest, which offers a wide program with the main theme of the reinterpretation of local rituals and stories and is directed by Vinicio Capossela. Secondly, the workshop "Translations" is an experimentation of a larger project called "e.colonia", which aims at creating a training and artisanal district, where designers and makers could work together to reinterpret the local artisan knowledge through art and design. The third case is "Cairano $7 x^{\prime \prime}$, a week a year where one of the smallest villages of Irpinia is repopulated around creative activities for young and old, with participants sleeping in the vacant houses of the country.

Figure 3. SponzFest: concert in the grotto.

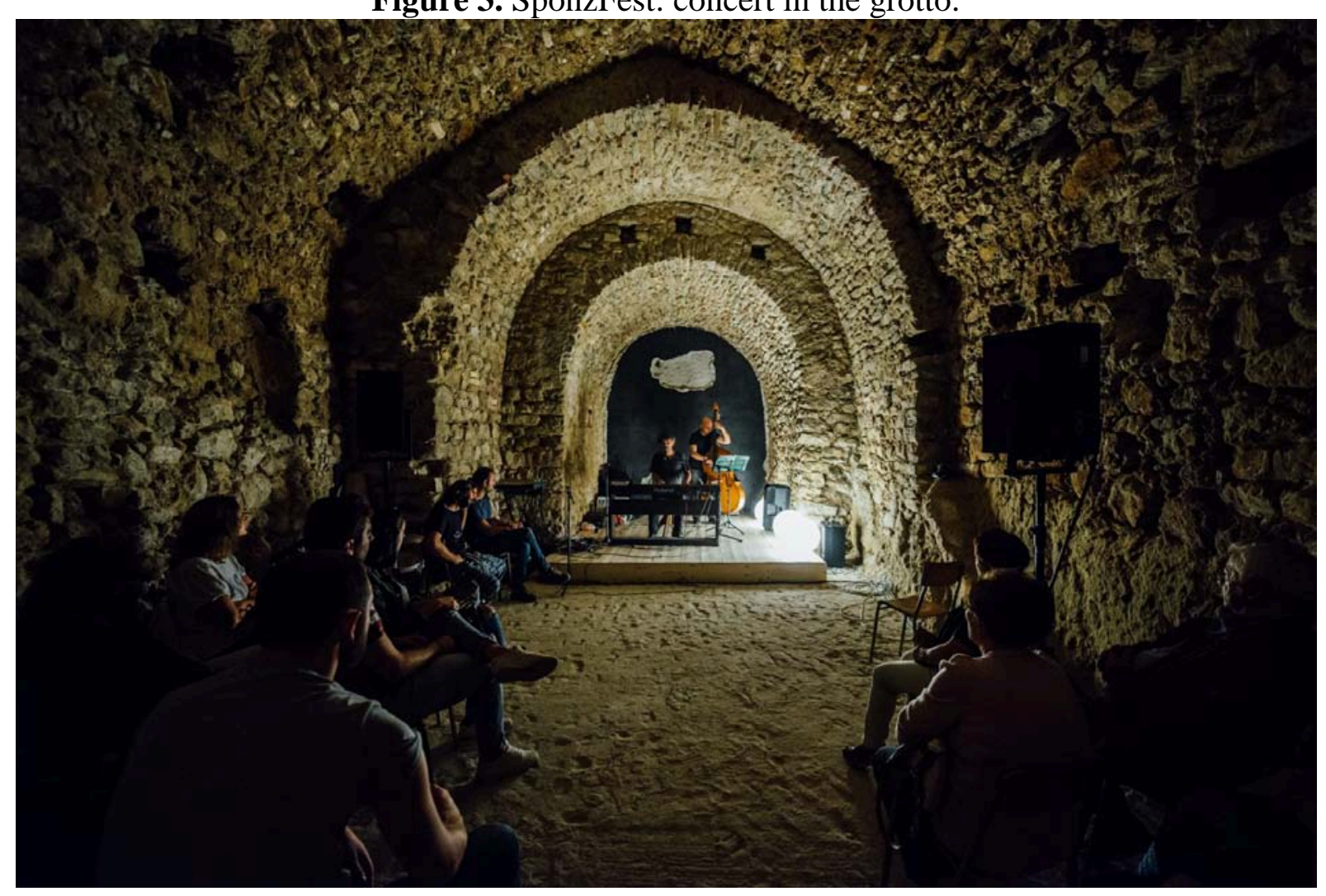

(C) Giuseppe Di Maio, 2017.

Figure 4. Translations workshop: new design for the ancient "stool" (Andrea Anastasio and his students design) 

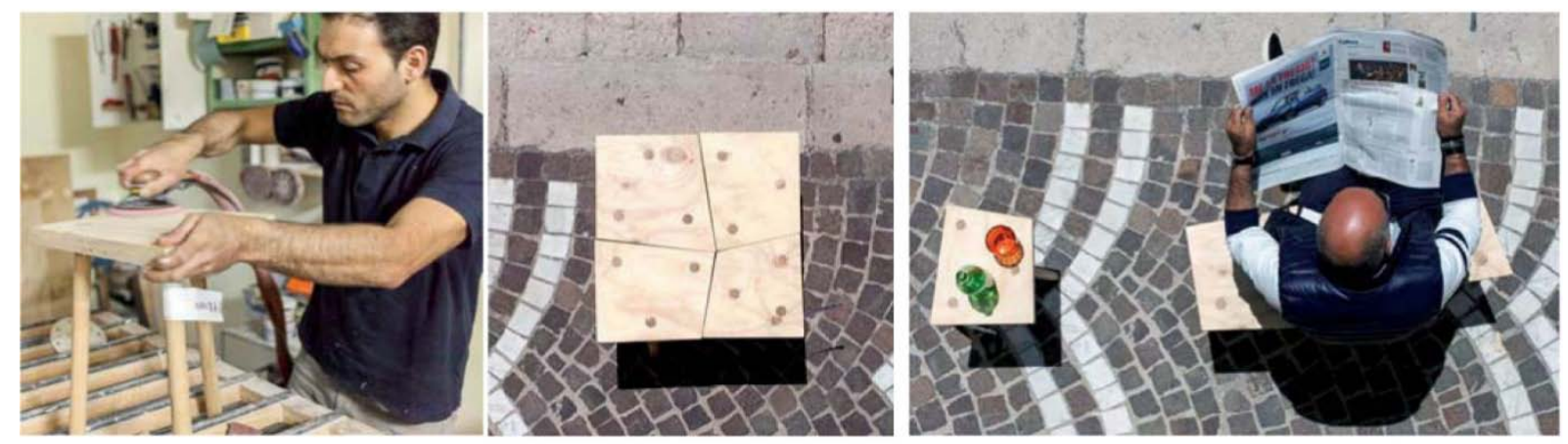

(C).Colonia, 2015.

Figure 5. Cairano 7x, 2010. Result of the construction workshop.

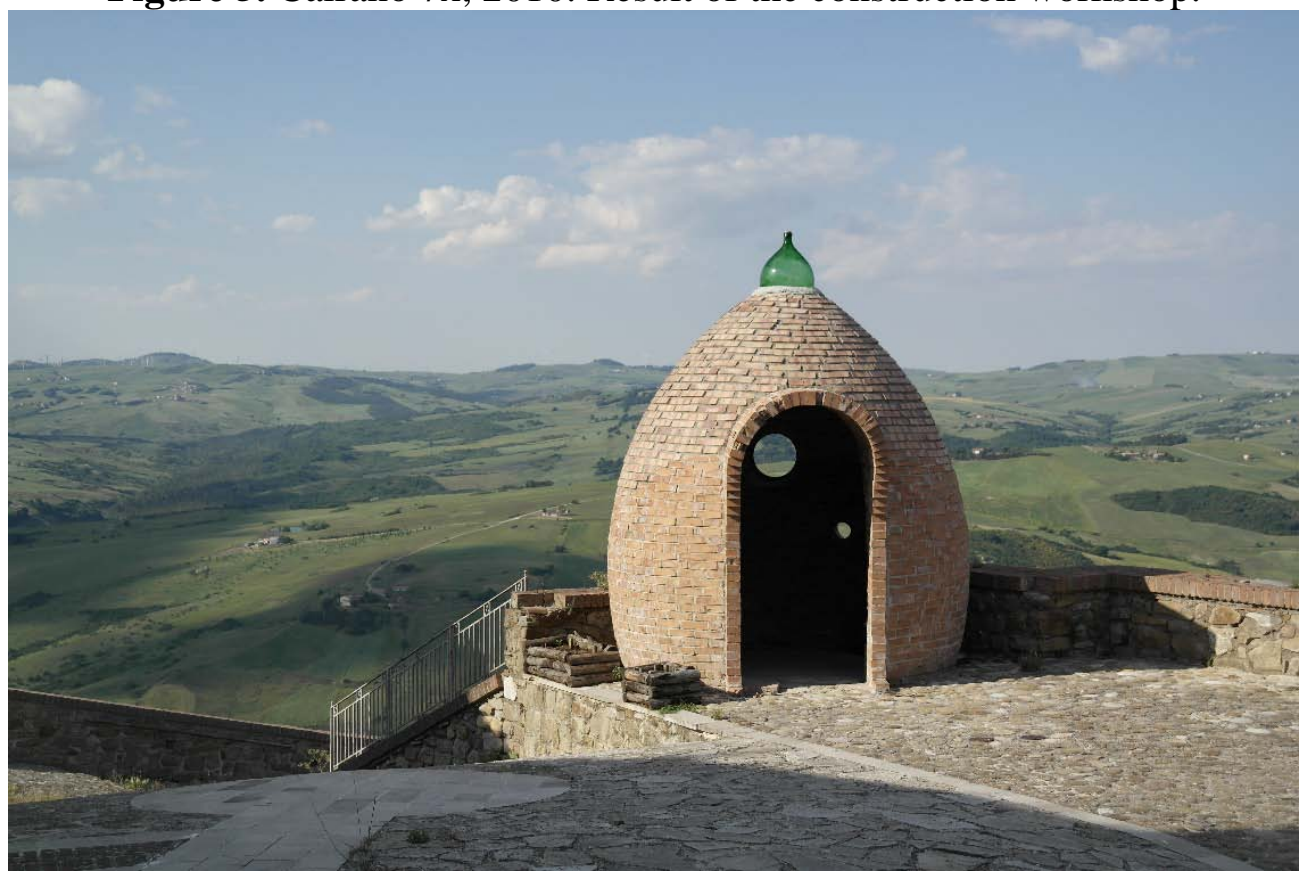

(C)Lucie Boissenin, 2017.

\section{Results}

The table (Tab. 1) shows the results of the analysis, highlighting 6 categories of data.

The section dedicated to the explanation of the actors shows differences between the three practices in almost all categories of data. Nevertheless, interesting common characteristics can be traced for each of them. All events are, in fact, characterized by numerous and diversified actors, with different skills. The activators are people with local roots, qualified, supported by a local group and an institution. This shows the resource potential that exists in the internal areas, which is unveiled on these occasions. Moreover, the presence of facilitators emerges, represented by groups of volunteers - local and not, organized and not, qualified and not - who support the process.

As far as the implementation process is concerned, the strategies are different but have in common the role of drivers of material and immaterial cultural heritage; so for the different actions, 
which have a common trace in the involvement and participation of the actors. For governance, the three experiences do not show a particular innovation, showing that there is much potential to develop in this field.

All practices have had, in the short term, positive results, especially in terms of number of people intercepted and relationships activated. In the medium term, the Translation workshop, although it stopped at the first edition, set in motion wide-ranging and durable relational processes. The format, which was probably very ambitious, clashed with the visions of the municipal administration. The SponzFest and Cairano 7x are growing events that show, despite the critical nature of the internal areas, long-term potential in terms of socio-economic development. These data demonstrate the validity of the creative vector and the attractiveness that these places generate also outside, despite the poor accessibility.

The section that evaluates the central elements of our debate highlights for the category of resilience that events move from the same risks and pressures and that the contexts share, in general, the same vulnerabilities. The Qualities of Resilient Systems of the City Resilience Framework help in interpreting the impact of practices on the resilience of social-urban systems. It emerges, in fact, that none of the practices has had (yet) repercussions on the planning of actions for the resilience of the territory at a normative level (Reflectiveness). All the practices, with different levels, satisfy instead the performances of Robustness, Resourcefulness, Inclusiveness, Flexibility, Redundancy. The SponzFest, besides having generally higher performance levels than the others, offers Integration performances, for the systematization of a plurality of tangible and intangible resources.

In the section dedicated to cultural heritage, tangible and intangible, it is clear that for all practices it has a leading role, with direct effects, in the case of SponzFests and Cairano 7x, on the recovery and maintenance of the built heritage. The practices are strongly linked to genius loci and to local communities; this result confirms the premises of the research that consider cultural heritage as a universal and unifying theme (ESDP 1999).

Table 1.Analysis of three temporary cultural creative experiences.

\begin{tabular}{|c|c|c|c|c|}
\hline \multicolumn{2}{|c|}{ PRACTICES NAMES } & SPONZ FEST & TRANSLATION & CAIRANO 7X \\
\hline \multirow{4}{*}{$\begin{array}{c}\text { GENERAL } \\
\text { INFORMATION }\end{array}$} & PLACE & $\begin{array}{c}\text { town of Calitri (about } \\
4500 \text { inhabitants) and } \\
\text { neighbouring towns }\end{array}$ & $\begin{array}{c}\text { town of Aquilonia } \\
\text { (about } 1700 \text { inhabitants) } \\
\text { in the old and new town } \\
+ \text { neighbouring town }\end{array}$ & $\begin{array}{c}\text { town of Cairano (about } \\
300 \text { inhabitants) }\end{array}$ \\
\hline & CONTEXT & \multicolumn{3}{|c|}{$\begin{array}{l}\text { Eastern Irpinia, inner periphery of the Campania region in the South of Italy. } \\
\text { It consists in } 25 \text { municipalities covering } 1.118 \mathrm{~km} 2 \text { and represents a } \\
\text { population of approximately } 65.000 \text { inhabitants. The landscapes is composed } \\
\text { by small urban settlements, spread in a wide natural context characterized by } \\
\text { wheat fields, vineyards and forests of oak. }\end{array}$} \\
\hline & $\begin{array}{c}\text { STATE OF } \\
\text { IMPLEMENTATION }\end{array}$ & $\begin{array}{l}\text { first edition in } 2013 \text {, } \\
\text { yearly seasonal event }\end{array}$ & only one edition in 2015 & $\begin{array}{l}\text { first edition in } 2009 \text {, } \\
\text { yearly seasonal event }\end{array}$ \\
\hline & OBJECTIVES & $\begin{array}{l}\text { to keep the traditions } \\
\text { and rituals alive; to } \\
\text { create community } \\
\text { empowerment }\end{array}$ & $\begin{array}{l}\text { to rediscover and } \\
\text { reactivate the } \\
\text { knowledge of local craft } \\
\text { traditions and the } \\
\text { cultural identity through }\end{array}$ & $\begin{array}{l}\text { to publicize the case of a } \\
\text { little village which tries } \\
\text { to survive; to bring the } \\
\text { village back to life } \\
\text { during a week; to inform }\end{array}$ \\
\hline
\end{tabular}




\begin{tabular}{|c|c|c|c|c|}
\hline & & & $\begin{array}{c}\text { art and design; to } \\
\text { experiment new } \\
\text { interactions between } \\
\text { places and communities }\end{array}$ & $\begin{array}{l}\text { the general public about } \\
\text { the opportunities inner } \\
\text { peripheries offer } \\
\text { (quietness, air quality, } \\
\text { experimentation places, } \\
\text { etc.) }\end{array}$ \\
\hline \multirow{7}{*}{ ACTORS } & \multirow[b]{2}{*}{ TARGET COMUNITY } & $\begin{array}{l}\text { local, national and } \\
\text { international public }\end{array}$ & \multirow{2}{*}{$\begin{array}{l}\text { inhabitants, students, } \\
\text { artists, designers and } \\
\text { local craftsmen }\end{array}$} & $\begin{array}{c}\text { regional and local } \\
\text { participants }\end{array}$ \\
\hline & & local community & & \begin{tabular}{|c|} 
public and private \\
stakeholders (institutions, \\
new inhabitants)
\end{tabular} \\
\hline & BENEFICIARY & $\begin{array}{c}\text { participants (national } \\
\text { (30\%) and regional } \\
\text { (70\%); accomodation } \\
\text { providers (hotels, } \\
\text { restaurants and } \\
\text { agrotourism, etc.); } \\
\text { Calitri shops, museums. }\end{array}$ & $\begin{array}{l}\text { participants (high } \\
\text { school students), } \\
\text { craftsmen, local } \\
\text { inhabitants, } \\
\text { accomodation providers }\end{array}$ & \begin{tabular}{|} 
participants (local and \\
regional inhabitants); \\
accomodation providers \\
of the village (bars, \\
B\&B) and the \\
neighbouring villages \\
(restaurants, hotels)
\end{tabular} \\
\hline & ACTIVATORS & $\begin{array}{c}\text { Vinicio Capossella } \\
\text { (artistic direction), } \\
\text { 'Sponziamoci' } \\
\text { association, La Cupa } \\
\text { association, } \\
\text { Municipality of Calitri } \\
\text { (applicant for European } \\
\text { funding) } \\
\end{array}$ & $\begin{array}{l}\text { +t studio architects, } \\
\text { researchers, GAL } \\
\text { CILSI }\end{array}$ & $\begin{array}{c}\text { Provisional } \\
\text { Communities' group - } \\
\text { now 'Irpinia } 7 \mathrm{x}^{\prime} \\
\text { association (composed of } \\
\text { inhabitants and artists of } \\
\text { the village and region) }\end{array}$ \\
\hline & ORGANIZERS & $\begin{array}{c}\text { Sponziamoci' } \\
\text { association, } \\
\text { municipalities } \\
\end{array}$ & $\begin{array}{l}\text { +t studio architects, } \\
\text { researchers }\end{array}$ & $\begin{array}{l}\text { Irpinia 7x association, } \\
\text { Cairano pro loco. }\end{array}$ \\
\hline & SUPPORTERS & $\begin{array}{l}\text { volunteers, technical } \\
\text { staff (electricians, } \\
\text { architects, engineers, } \\
\text { surveyors, carpenters, } \\
\text { etc.), State Railways } \\
\text { Foundation, Media } \\
\text { Partners, cultural } \\
\text { associations, etc. }\end{array}$ & $\begin{array}{l}\text { director, tutors (non } \\
\text { residents architects- } \\
\text { teachers-artists- } \\
\text { designers; GAL CILSI; } \\
\text { Municipality of } \\
\text { Aquilonia; craftsmen; } \\
\text { accomodation } \\
\text { providers; } \\
\text { Confartigianato (trade } \\
\text { association) } \\
\end{array}$ & $\begin{array}{l}\text { volunteers (Cairano } \\
\text { inhabitants), municipality } \\
\text { of Cairano }\end{array}$ \\
\hline & ECONOMIC PARTNERS & $\begin{array}{c}\text { GAL CILSI, Campania } \\
\text { Region, crowdfunding } \\
\text { (local sponsors), } \\
\text { municipalities } \\
\end{array}$ & $\begin{array}{l}\text { GAL CILSI, local } \\
\text { sponsors }\end{array}$ & $\begin{array}{c}\text { a private sponsor, } \\
\text { municipality of Cairano, } \\
\text { Cairano pro loco, 'Irpinia } \\
\text { 7x' association } \\
\end{array}$ \\
\hline \multirow[t]{2}{*}{ IMPLEMENTATION } & STRATEGY & $\begin{array}{l}\text { to reinterpretate the } \\
\text { places and traditions } \\
\text { through the setting-up of } \\
\text { scenography and } \\
\text { temporary installations, } \\
\text { and reusing semi- } \\
\text { abandoned places }\end{array}$ & $\begin{array}{l}\text { to experiment a training } \\
\text { program which could be } \\
\text { a part of a larger project } \\
\text { called "e.colonia", } \\
\text { aimed at creating an } \\
\text { handcraft district to } \\
\text { reactivate the } \\
\text { abandoned old town } \\
\text { and developing a new } \\
\text { economy. } \\
\end{array}$ & \begin{tabular}{|} 
to offer a plurality of \\
activities in order to \\
bring to Cairano lots of \\
people with different \\
interests and reuse public \\
spaces and empty houses \\
for a week \\
\end{tabular} \\
\hline & ACTIONS & events (musical shows, & a one-week workshop & gardening and building \\
\hline
\end{tabular}




\begin{tabular}{|c|c|c|c|c|c|}
\hline & & & $\begin{array}{l}\text { workshops, conferences, } \\
\text { discussions, walks, etc.); } \\
\text { temporary architecture } \\
\text { to reuse underused } \\
\text { spaces; creation of } \\
\text { partnerships with policy } \\
\text { activators (F.S } \\
\text { Foundation, } \\
\text { municipalities, citizen's } \\
\text { committee, etc.) }\end{array}$ & $\begin{array}{l}\text { during which three } \\
\text { teams of designers, } \\
\text { artists, craftsmen, } \\
\text { students and young } \\
\text { makers were to produce } \\
\text { prototypes of rural } \\
\text { design objects. }\end{array}$ & $\begin{array}{l}\text { workshops, cinema and } \\
\text { theater courses, games } \\
\text { for children, discussions, } \\
\text { walks through the } \\
\text { village; shared meals }\end{array}$ \\
\hline & \multicolumn{2}{|c|}{ GOVERNANCE } & $\begin{array}{l}\text { Municipality of Calitri } \\
\text { with the artistic } \\
\text { direction and the } \\
\text { "Sponziamoci } \\
\text { association" }\end{array}$ & $\begin{array}{l}\text { GAL with the } \\
\text { organizers' group (local } \\
\text { inhabitants with } \\
\text { architecture and } \\
\text { research skills) }\end{array}$ & $\begin{array}{c}\text { decisions are taking } \\
\text { during the meetings of } \\
\text { the 'Irpinia } 7 \mathrm{x}^{\prime} \\
\text { association, which take } \\
\text { place } 6 / 7 \text { times a year } \\
\text { and are opened to general } \\
\text { public }\end{array}$ \\
\hline \multirow{3}{*}{ RESULTS } & \multirow[t]{2}{*}{ EFFECTS } & $\begin{array}{c}\text { IN THE } \\
\text { SHORT TERM }\end{array}$ & $\begin{array}{l}\text { working opportunities } \\
\text { for the little and } \\
\text { medium-scale local } \\
\text { companies; creation of } \\
\text { relationships between } \\
\text { several actors: local } \\
\text { community, possible } \\
\text { new inhabitants, } \\
\text { associations, } \\
\text { professionals }\end{array}$ & $\begin{array}{l}\text { dissemination of the } \\
\text { local traditions and } \\
\text { knowledge, creation of } \\
\text { relationships between } \\
\text { several players : } \\
\text { inhabitants, students, } \\
\text { craftsmen, artists ; } \\
\text { realization of prototypes } \\
\text { and projects for the } \\
\text { renewal of local } \\
\text { traditions } \\
\end{array}$ & $\begin{array}{c}\text { temporary repopulation } \\
\text { of the village; } \\
\text { publicization of the } \\
\text { village as a potential } \\
\text { tourist destination. }\end{array}$ \\
\hline & & $\begin{array}{l}\text { IN THE } \\
\text { MEDIUM } \\
\text { TERM }\end{array}$ & $\begin{array}{l}\text { strengthening of the } \\
\text { synergy between private } \\
\text { and public actors; } \\
\text { creation of relationships } \\
\text { between the } \\
\text { participating } \\
\text { municipalities and the } \\
\text { local companies } \\
\end{array}$ & $\begin{array}{l}\text { creation of relationships } \\
\text { between the workshop's } \\
\text { participants; working } \\
\text { opportunities for the } \\
\text { local crafts }\end{array}$ & $\begin{array}{l}\text { legitimization of a larger } \\
\text { project which aims at } \\
\text { creating a theater school }\end{array}$ \\
\hline & \multicolumn{2}{|c|}{ WEAKNESSES } & $\begin{array}{l}\text { delay of the regional } \\
\text { founds; lack of } \\
\text { accommodation and } \\
\text { transport facilities; lack } \\
\text { of experience of the } \\
\text { local human resources } \\
\text { (they aren't always able } \\
\text { to answer the client's } \\
\text { requests); financial } \\
\text { weakness of the local } \\
\text { municipalities }\end{array}$ & $\begin{array}{l}\text { event limited to one } \\
\text { edition (small results); } \\
\text { lack of support from } \\
\text { local institutions }\end{array}$ & $\begin{array}{l}\text { event limited to one } \\
\text { week a year; lack of } \\
\text { transport accessibility } \\
\text { and restaurant facilities. }\end{array}$ \\
\hline $\begin{array}{l}\text { CULTURAL } \\
\text { HERITAGE }\end{array}$ & ROLE & TANGIBLE & $\begin{array}{l}\text { leading role: castle and } \\
\text { caves which are } \\
\text { receiving some events }\end{array}$ & $\begin{array}{l}\text { leading role: the idea is } \\
\text { born to re-inhabiting } \\
\text { Carbonara (the old } \\
\text { town) + the workshop } \\
\text { groups are inspired by } \\
\text { the traditional objects } \\
\text { keeping in the }\end{array}$ & $\begin{array}{l}\text { leading role: houses of } \\
\text { the village which are } \\
\text { receiving the } \\
\text { participants, public } \\
\text { spaces for the activities }\end{array}$ \\
\hline
\end{tabular}




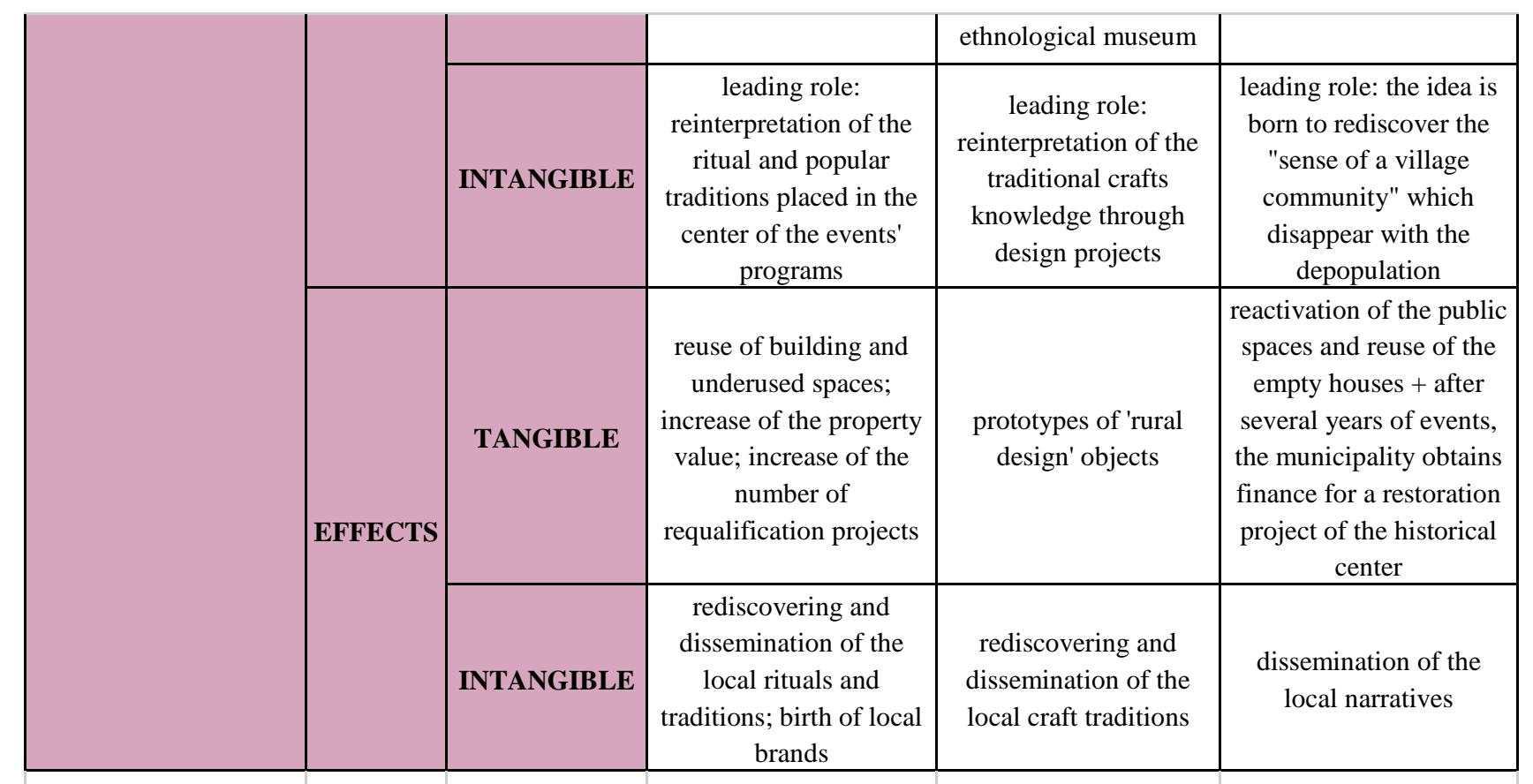

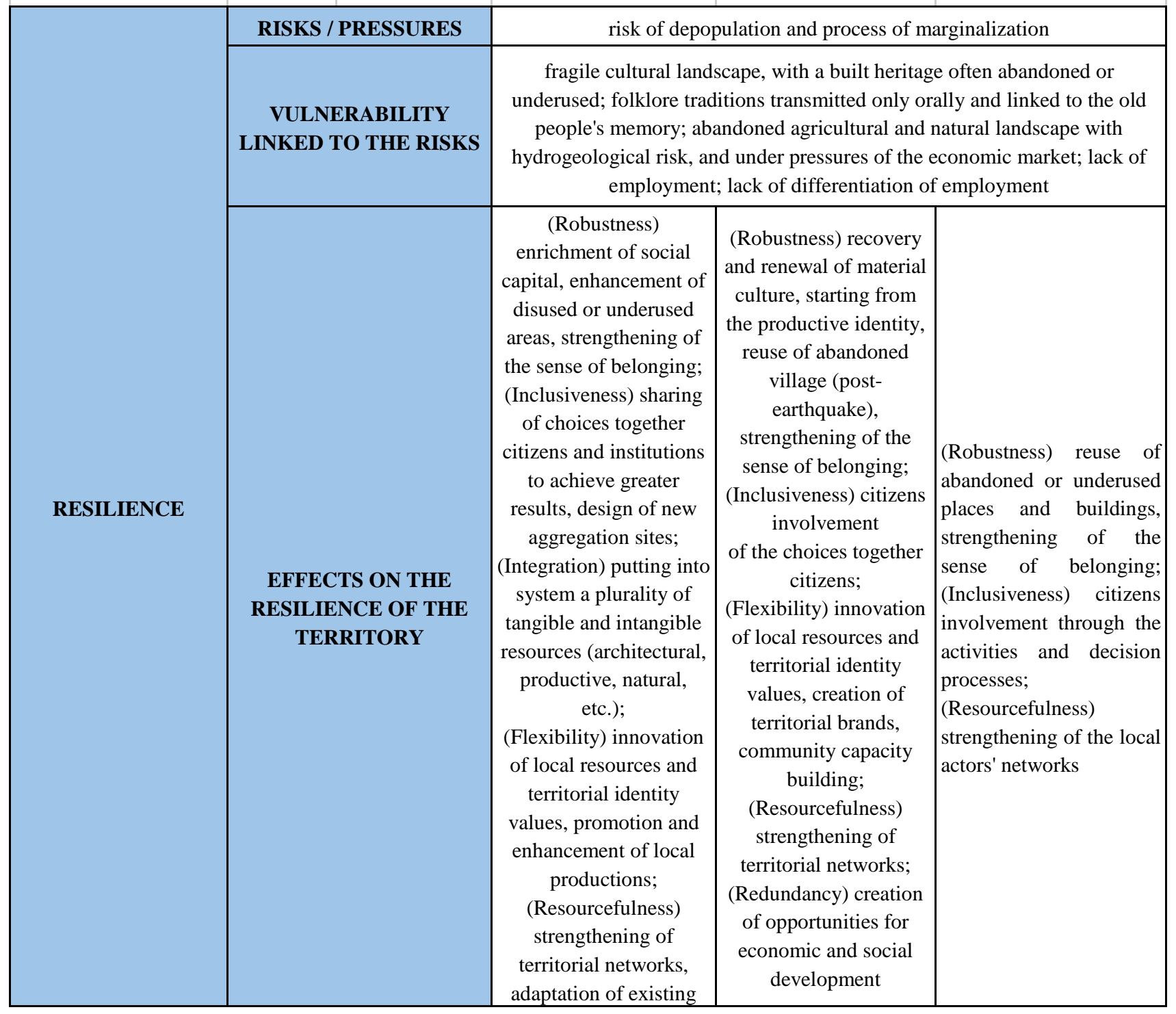




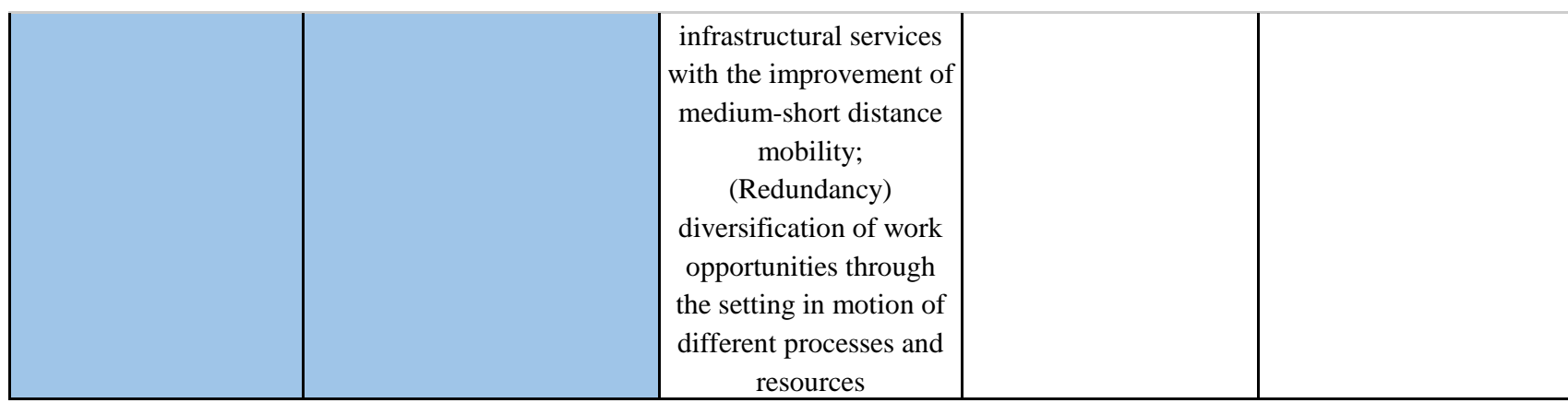

\section{Discussion}

The results of the analysis have shown that practices carried out by communities and which have as their driver the cultural heritage, strongly linked to genius loci, can contribute to the resilience of the social-urban system and to the improvement of the quality of life. In particular, the value of creative activity for innovation of indigenous or traditional knowledge and practices (Flexibility) emerges. This driver helps to stimulate the adaptive capacity of the population, understood as the ability to renew and reinterpret its own cultural heritage. In this sense, the recognition of the value of cultural heritage in improving the quality of life and facing the main local and global challenges is consolidated; moreover, the social demand is directed towards new imaginations. In some cases, creative activity has been expressed in practices through the reuse of urban spaces, also through the setting up of scenic designs. In this way, unexpressed qualities of places can be revealed and community identity strengthened. In some cases, architectures are designed to induce aggregation and to stimulate sharing, involvement, participation.

A plurality of actors and skills has proved to be a fertile element for all practices. The relationship between expert and common knowledge helps, in fact, the activation of virtuous processes of knowledge, through the decoding of values to be attributed to cultural heritage, and innovation. In the case of the inner peripheries, the material culture is vulnerable and risks to disappear, if entrusted to the memory of an elderly population. Signs of rebirth can be seen in the recent trend towards the return to the places of origin of young people with a higher education or in the so-called new inhabitants, who often bring with them a wealth of expertise and creativity (Battaglini and Corrado 2014).

The activation (at different levels) of territorial, social, economic and political networks contributed to the quality of the events, also in terms of their effects on the resilience of the system. Moreover, the mobilization of resources of different nature and different processes has contributed to the diversification of opportunities.

The examined initiatives, in which the local community is the activator and protagonist, proved to be a laboratory for educating the population to take collective care of its heritage, demonstrating the potential that a cohesive community can develop. At the same time, such practices can guide institutions in directing their actions more effectively. It emerges, in fact, the absence of effects of initiatives on governance and on the traditional tools of regulations for the management of 
uncertainty and changes. This data has stimulated the search for initiatives that can support this process of innovation, placing themselves as places of learning, participation and decision.

To this end, the paper proposes to carry out Resilience Laboratories. The project starts in previous researches of the authors (Pinto et al. 2018), combining the Resilience Assessment's theory and practices with the Transition Movement's methods for learning and participating. The project foresees the establishment of a permanent body of intermediation between the public administration and the local community. In particular, it is based on the involvement of different stakeholders and on the meeting between expert knowledge and common knowledge in the different phases of the risk management process (knowledge, planning, implementation, management/monitoring).It aims primarily at increasing the data flows needed to dynamically update changes in the conditions of context and to activate the related changes (Paganin et al. 2018). In addition, the Resilience Laboratories support the decision-making and implementation process to trigger shared strategies and innovative forms of governance. Following the guidelines of the Sendai Framework (point 36), the model is proposed as a protocol of collaboration between (open) communities, researchers, decision makers, designers, experts from different disciplines, entrepreneurs.

The inner peripheries can be an effective place of experimentation. The ground prepared by these festivals, in terms of awareness and empowerment of local communities, is fertile. Resilience Laboratories could be a tool to support local governance in capitalizing the good community-led practices.

\section{Conclusions}

The research intended to highlight that resilience represents an approach capable of interpreting the complexity and changing nature of settlement systems and also the role to be assigned to the community in this context. Resilience, in fact, represents the paradigm of a city capable of responding to the changes imposed by socio-economic pressures, preserving those values that give it stability, building through participation a shared collective sense and places where all citizens can identify (Fusco Girard 2010, Fabbricatti 2013).

Inner peripheries are privileged environment to observe the bottom-up dynamics emerging around the cultural heritage and its use as driving resource in searching for economic and social alternatives. Public policies on "community resilience" are being promoted at the regional, national and international levels, but too rarely these meet the peculiarities of the contexts and local interests, that is why we propose resilience laboratories, as a tool for mediation between the actors. However, it remains to define how to implement such a mediation structure in the complex administrative and political system of Irpinia, and more generally in Italy. Despite a prepared ground and to the emergence of a heritage community, there is still a reluctance of political actors in these areas to work together. Will resilience laboratories be able to overcome this barrier to promote integrated risk management?

\section{Acknoledgments}


IDEX Univ. Grenoble Alpes / LabEx AE\&CC

\section{References and Notes}

AA.VV. 2017. PROFECY - Processes, Features and Cycles of Inner Peripheries. Luxembourg: ESPON EGTC.

AA.VV. 2014. Strategia Nazionale per le Aree Interne: definizione, obiettivi, strumenti $e$ governance, Roma : Agenzia per la Coesione Territoriale.

AA.VV. 2004. Codice dei beni culturali e del paesaggio. D. Lgs 22/01/2004 n. 42.

Agosti C. 2018.Nuovi approcci per la gestione dei beni comuni in ambito urbano. In Lucarelli M.T., Mussinelli E., Daglio L., Progettare resiliente.Milano: Maggioli, pp. 314-322.

Arup International Development. 2014. City Resilience Framework. London: ARUP.

Battaglini L., Corrado F. 2014. The return to the rural-mountain lands: different aspects of an ongoing phenomenon. Scienze del Territorio 2: 79-94. http://dx.doi.org/10.13128/Scienze_Territorio14324.

Biancamano P.F., Viola S., Pinto M.R. 2013. Sharing knowledge to promote active protection. Case study: Sassano, Cilento National Park. BDC13: 145-156.

Beel D.E. 2017. Cultural resilience: the production of rural community heritage, digital archives and the role of volunteers. Journal of Rural Studies 54: 459-468.

Camagni R. 2017. Regional Competitiveness: Towards a Concept of Territorial Capital. In Capello R. Seminal Studies in Regional and Urban Economics. Berlin: Springer, pp. 33-34.

Cerreta M., Daldanise G., Sposito S. 2018. Culture-led regeneration for urban spaces: Monitoring complex values networks in action. Urbani izziv 29: 9-27.DOI: 10.5379/urbani-izziv-en-2018-29supplement-001.f

Council of Europe. 2005. Framework Convention on the Value of Cultural Heritage for Society (Faro Convention). Faro (Portugal).

Council of Europe. 2000. European Landscapes Convention. Florence (Italy).

European Spatial Development Perspective. 1999. Towards Balanced and Sustainable Development of the Territory of the European Union. Luxembourg: Office for Official Publications of the European Communities.

Fabbricatti K. 2013. Le sfide della città interculturale. Milano: Franco Angeli.

Fusco Girard L. 2013. The City and the Territory System:Towards the "New Humanism” Paradigm. Agriculture and Agricultural Science Procedia 8: 542-551.

Fusco Girard L. 2010. Sustainability, creativity, resilience.Towards new development strategies of port areas through evaluation processes. International Journal of Sustainable Development 1-2: 161-184. DOI: 10.1504/IJSD.2010.035106

Gunderson L.H., Folke C. 2005. Resilience-Now More than Ever (editorial). Ecology and Society, 10 (2), at http://www.ecologyandsociety.org/vol10/iss2/art22/. 
Holling C.S. 2001. Understanding the complexity of economic, ecological and social system. Ecosystems 4: 390-405.

Hosagrahar J. 2015. UNESCO Regional Report on Urban Conservation and Regeneration in South Asia, Iran and Afghanistan. Paper presented at International Conference on Culture for Sustainable Cities, Dec. 10-12. Available online: http://www.unesco.org/culture/hangzhoucongress/UNESCO_Hangzhou_Conference_PlenaryIV_PPT.pdf

Magnaghi A., De Bonis L., Giovagnoli M., Pazzagli R. 2017. Qualche appunto e suggestione dal convegno SDT di Matelica. Available online: http://www.societadeiterritorialisti.it/wpcontent/uploads/2017/10/Matelica_Avanzamenti_def.pdf

Magnaghi A. 2012. Il territorio bene comune. Firenze: Firenze University Press.

O’Connell D.A., Walker B., Abel N., Grigg N. 2015. The Resilience, Adaptation and Transformation Assessment Framework: From Theory to Application. Canberra: CSIRO. http://www.stapgef.org/sites/default/files/documents/CSIRO-STAP-Resilience-Adaptation-

Transformation-Assessment-Framework-Report.pdf

Oppido S., Ragozino S. Micheletti S. 2018. Sharing responsibilities to regenerate publicness and cultural values of marginalized landscapes: Case of Alta Irpinia, Italy. Urbani izziv 29: 125-142.

Paganin, G., Talamo C., Atta N., 2018. Knowledge, management and resilience of urban and territorial systems. TECHNE 15: 124-133.DOI: 10.13128/Techne-22126.

Pinto M.R., Fabbricatti K., Boissenin L. 2018. Applying Resilience Thinking for the Cultural Landscape of the inner areas: new tools of knowledge and adaptive management. Abitare la Terra 46-47: 66-69.

Pinto M.R., Viola S. 2016. Cultura materiale e impegno progettuale per il recupero: Living Lab nel Parco del Cilento. TECHNE 12: 223-229.

Settis S. 2005. Battaglie senza eroi: i beni culturali tra istituzioni e profitto, Milano: Electa.

Terranova, F. 2018. Observations Regarding a Historical/Critical Process.From 20th-Century SocioEconomic Planning to Resilience.TECHNE15: 21-26. https://doi.org/10.13128/Techne-23196.

UN, 2015. Transforming our world: the 2030 Agenda for Sustainable Development, A/RES/70/1, available at https://sustainabledevelopment.un.org/content/documents/21252030\%20Agenda\%20 for\%20Sustainable\%20Development\%20web.pdf [accessed June 11, 2016].

UNESCO. 2001. Recommendation on the Historic Urban Landscape, Paris: UNESCO World Heritage Centre.

UNISDR. 2015. Sendai Framework 2015-2030. Geneva: United Nations Office for Disaster Risk Reduction.

Walker B., Salt D. 2012. Resilience practice. Building capacity to absorb disturbance and maintain function. Washington D.C.: Island Press.

(C) 2018 by the authors; licensee MDPI and IFoU, This article is an open access article distributed under the terms and conditions of the Creative Commons Attribution license. 